\section{APEM}

\title{
Effect of a milling cutter diameter on distortion due to the machining of thin wall thin floor components
}

\author{
Sridhar, G. ${ }^{a,}{ }^{*}$, Ramesh Babu, P. ${ }^{a}$ \\ ${ }^{a}$ Mechanical Engineering Department, University College of Engineering, Osmania University, Hyderabad, India
}

\begin{abstract}
A B S T R A C T
Machining of prismatic blocks, removing material up to $85 \%$ on CNC machines to produce thin wall thin floor monolithic components replacing multi part assemblies has become common in aerospace industries. The greatest challenge when machining these components is part distortion. Selecting the right kinds of tools and machining parameters is of utmost importance in minimizing distortion. One of the important parameters is the size (diameter) of the cutter. Generally, within a production scenario, the selecting the size of the cutter is driven by the productivity and geometrical constraints of the component. Experience shows that selecting the wrong size of the cutter can lead to distortion and the selecting of a correct size of the cutter depends on heuristics. In order to understand the effect of cutter diameter on distortion, machining experiments were carried out by using different sizes of milling cutter, at constant feed, speed, depth of cut and volume of material removal rate, on a representative thin wall thin floor aluminium alloy (2014A T651) component, holding the part from the bottom, using a shop made vacuum fixture. Machining simulations were also carried out to understand the machining characteristics with any change in cutter diameter at constant feed, speed, depth of cut, and material removal rate. Experimental results show that the diameter of a milling cutter has an effect on distortion at constant feed, speed, depth of cut, and volume of material removal rate.
\end{abstract}

\section{ARTICLE INFO}

Keywords:

Milling

Thin wall thin floor

Distortion

Cutter size

*Corresponding author:

Garimella_s@yahoo.com

(Sridhar, G.)

Article history:

Received 28 December 2014

Revised 16 August 2015

Accepted 19 August 2015 


\title{
Učinek premera rezkala na deformacijo med obdelavo nizkih tankostenskih komponent
}

\author{
Sridhar, G. ${ }^{\text {a, }}{ }^{,}$, Ramesh Babu, P.
}

${ }^{a}$ Mechanical Engineering Department, University College of Engineering, Osmania University, Hyderabad, India

\section{POVZETEK}

Obdelava prizmatičnih obdelovalcev za izdelavo nizkih tankostenskih monolitnih komponent, kjer predstavlja CNC-obdelava z odstranjevanjem materiala do $85 \%$ vseh obdelovalnih postopkov, s pridom nadomešča izdelavo izdelkov, sestavljenih iz več sestavin, še posebej za potrebe letalske industrije. Največji izziv pri obdelavi takšnih izdelkov je njihova deformacija. Za zmanjšanje deformacije sta izbiri ustreznega orodja in obdelovanih parametrov zelo pomembni. Eden izmed pomembnih parametrov je premer rezkala. V splošnem izbiro velikosti rezkala narekujejo želena produktivnost in geometrijske omejitve komponente. Izkušnje kažejo, da izbira napačne velikosti rezkala lahko vodi do deformacij komponente. Da bi razumeli vpliv premera rezkala na deformacije smo izvedli preizkuse $\mathrm{z}$ različnimi velikostmi rezkala pri konstantni obdelovalni hitrosti, podajanju, globini reza in volumnu odstranjenega materiala. Tankostenska komponenta je bila iz aluminijeve zlitine (2014A T651), vpeta pa je bila od spodaj s pomočjo vakuumske vpenjalne priprave. Da bi bolje razumeli značilnosti obdelave, smo izvedli tudi simulacije obdelave za vsak premer rezkala pri konstantni obdelovalni hitrosti, podajanju in globini reza. Eksperimentalni rezultati so pokazali, da ima premer rezkala vpliv na deformacije pri konstantni obdelovalni hitrosti, podajanju, globini reza in volumnu odstranjenega materiala.

\section{PODATKI O ČLANKU}

Ključne besede:

Rezkanje

Nizke tankostenske komponente

Deformacije

Velikost rezkala

*Kontaktna oseba:

Garimella_s@yahoo.com

(Sridhar, G.)

Zgodovina članka:

Prejet 28. decembra 2014

Popravljen 16. avgusta 2015

Sprejet 19. avgusta 2015 


\section{References}

[1] Sim, W.M. (2010). Challenges of residual stress and part distortion in the civil airframe industry, International Journal of Microstructure and Materials Properties, Vol. 5, No. 4-5, 446-455, doi: 10.1504/IJMMP.2010.037621.

[2] Chantzis, D., Van-der-Veen, S., Zettler, J., Sim, W.M. (2013). An industrial workflow to minimise part distortion for machining of large monolithic components in aerospace industry, Procedia CIRP, Vol. 8, 281-286. doi: 10.1016/ j.procir.2013.06.103.

[3] Sridhar, G., Babu, P.R. (2013). Understanding the challenges in machining thin walled thin floored avionics components, International Journal of Applied Science and Engineering Research, Vol. 2, No. 1, 93-100, doi: 10.6088/ ijaser.020100010.

[4] Chatelain, J.F., Lalonde, J.F., Tahan, A.S. (2011). A comparison of the distortion of machined parts resulting from residual stresses within workpieces, In: Proceedings of the $4^{\text {th }}$ International Conference on Manufacturing Engineering, Quality and Production Systems (MEQAPS '11), Barcelona, Spain, 79-84.

[5] Ma, K., Goetz, R., Srivatsa, S.K. (2010). Modeling of residual stress and machining distortion in aerospace components, ASM Handbook, ASM.

[6] Hornbach, D., Prevéy, P. (1998). Development of machining procedures to minimize distortion during manufacture, In: Proceedings of the 17th Heat Treating Society Conference and Exposition: Heat Treating, ASM, Ohio, 13-18.

[7] Cui, H., Jung, J.Y., Moon, D.H. (2005). The selection of machining parameters to minimize deformation caused by heat, In: Proceedings of the Fall Conference of Society of Korea Industrial and Systems Engineering, Korea.

[8] Wang, Z.J., Chen, W.Y., Zhang, Y.D., Chen, Z.T., Liu, Q. (2005). Study on the machining distortion of thin-walled part caused by redistribution of residual stress, Chinese Journal of Aeronautics, Vol. 18, No. 2, 175-179, doi: 10.1016/S1000-9361(11)60325-7.

[9] Dong, H.Y., Ke, Y.L. (2006). Study on machining deformation of aircraft monolithic component by FEM and experiment, Chinese Journal of Aeronautics, Vol. 19, No. 3, 247-254, doi: 10.1016/S1000-9361(11)60352-X.

[10] Denkena, B., de León, L. (2008). Machining induced residual stress in wrought aluminium parts, In: Proceedings of $2^{\text {nd }}$ International Conference on Distortion Engineering, Bremen, Germany, 107-114.

[11] Marusich, T.D., Stephenson, D.A., Usui, S., Lankalapalli, S. (2009). Modeling capabilities for part distortion management for machined components, from http://www.thirdwavesys.com/ accessed August 16, 2015.

[12] Marusich, T.D., Usui, S., Marusich, K.J. (2008). Finite element modeling of part distortion, In: Xiong, C., Liu, H., Huang, Y., Xiong, Y. (eds.), Intelligent robotics and applications, Lecture notes in computer science, Vol. 5315, Springer, Berlin Heidelberg, 329-338, doi: 10.1007/978-3-540-88518-4 36.

[13] Bi, Y.B., Cheng, Q.L., Dong, H.Y., Ke, Y.L. (2009). Machining distortion prediction of aerospace monolithic components, Journal of Zhejiang University SCIENCE A, Vol. 10, No. 5, 661-668, doi: 10.1631/jzus.A0820392.

[14] Yang, Y., Wang, Y.L. (2010). Analysis and control of machining distortion for aircraft monolithic component aided by computer, In: Information and Computing (ICIC), 2010 Third International Conference on Information and Computing, IEEE, Vol. 3, 280-283, doi: 10.1109/ICIC.2010.256.

[15] Belgasim, O., El-Axir, M.H. (2010). Modeling of residual stresses induced in machining aluminum magnesium alloy (Al-3Mg), In: Proceedings of the World Congress on Engineering, Vol. 2, London, UK, 1268-1273.

[16] Izamshah, R.A., Mo, J., Ding, S.L. (2010). Finite element analysis of machining thin-wall parts, Key Engineering Materials, Vol. 458, 283-288, doi: 10.4028/www.scientific.net/KEM.458.283.

[17] Chatelain, J.F., Lalonde, J.F., Tahan, A.S. (2012). Effect of residual stresses embedded within workpieces on the distortion of parts after machining, International Journal of Mechanics, Vol. 6, No. 1, 43-51.

[18] Songtao, W., Minli, Z., Yihang, F., Zhe, L. (2012). Cutting parameters optimization in machining thin-walled characteristics of aircraft engine architecture based on machining deformation, Advances in Information Sciences and Service Sciences, Vol. 4., No. 10, 244-252, doi: 10.4156/AISS.vol4.issue10.29.

[19] Sridhar, G., Ramesh Babu P. (2013). Cutting parameter optimization for minimizing machining distortion of thin wall thin floor avionic components using Taguchi technique, International Journal of Mechanical Engineering and Technology, Vol. 4, No. 4, 71-78.

[20] Huang, X., Sun, J., Li, J., Han, X., Xiong, Q. (2013). An experimental investigation of residual stresses in high-speed end milling 7050-T7451 aluminum alloy, Advances in Mechanical Engineering, Vol. 5, doi: 10.1155/2013/ 592659.

[21] Tang, Z.T., Liu, Z.Q., Pan, Y.Z., Wan, Y., Ai, X. (2009). The influence of tool flank wear on residual stresses induced by milling aluminum alloy, Journal of Materials Processing Technology, Vol. 209, No. 9, 4502-4508, doi: 10.1016/i.jmatprotec.2008.10.034.

[22] Jiang, X., Li, B., Yang, J., Zuo, X.Y., Li, K. (2013). An approach for analyzing and controlling residual stress generation during high-speed circular milling, The International Journal of Advanced Manufacturing Technology, Vol. 66, No. 9-12, 1439-1448. doi: 10.1007/s00170-012-4421-8.

[23] Jiang, X., Li, B., Yang, J., Zuo, X.Y. (2013). Effects of tool diameters on the residual stress and distortion induced by milling of thin-walled part, The International Journal of Advanced Manufacturing Technology, Vol. 68, No. 1-4, 175-186. doi: 10.1007/s00170-012-4717-8.

[24] lzamshah, R., Yuhazri, M.Y., Hadzley, M., Ali, M.A., Subramonian, S. (2013). Effects of end mill helix angle on accuracy for machining thin-rib aerospace component, Applied Mechanics and Materials, Vol. 315, 773-777, doi: 10.4028/www.scientific.net/AMM.315.773.

[25] Yanda, H., Ghani, J.A., Haron, C.H.C. (2010). Effect of rake angle on stress, strain and temperature on the edge of carbide cutting tool in orthogonal cutting using FEM simulation, Journal of Engineering and Technological Sciences, Vol. 42, No. 2, 179-194. doi: dx.doi.org/10.5614/itbj.eng.sci.2010.42.2.6. 
[26] Gardner, J.D., Vijayaraghavan, A., Dornfeld, D.A. (2005). Comparative study of finite element simulation software, Laboratory for Manufacturing and Sustainability, UC Berkeley: Laboratory for Manufacturing and Sustainability, from http://escholarship.org/uc/item/8cw4n2tf, accessed August 16, 2015.

[27] Shaw, M.C. (2005). Metal cutting principles, $2^{\text {nd }}$ edition, Oxford University Press, Oxford, UK.

[28] Jain, K.C., Chitale, A.K. (2010). Textbook of production engineering, $2^{\text {nd }}$ edition, PHI Learning Pvt. Ltd., Delhi, India. 